\title{
Effect of carrier and axial ligand on the photocatalytic activity of cobalt thioporphyrazine
}

\author{
Yi Liu, Xuanmu Zhou, Zhehui Zhang*, Bingguang Zhang, Kejian Deng\# \\ Key Laboratory of Catalysis and Material Sciences of the State Ethnic Affairs Commission \& Ministry of Education, College of Chemistry and Material \\ Sciences, South-Central Universities for Nationalities, Wuhan 430074, Hubei, China
}

\section{A R T I C L E I N F O}

\section{Article history:}

Received 30 August 2016

Accepted 15 October 2016

Published 5 February 2017

\section{Keywords:}

Cobalt thioporphyrazine

Photocatalytic activity

Alumina

$\mathrm{SiO}_{2} @ \mathrm{Fe}_{3} \mathrm{O}_{4}$

Axial direction ligand

Sodium azide

\begin{abstract}
A B S T R A C T
The photocatalytic activity of cobalt octakis(butylthio) porphyrazine ( $\mathrm{CoPz}(\mathrm{BuS}) 8$ ) was assessed through photodegradation of the dye rhodamine $\mathrm{B}(\mathrm{RhB})$ in water under irradiation with a Xe lamp and aerated conditions. The photocatalytic activity of $\mathrm{CoPz}(\mathrm{BuS})_{8}$ loaded on $\mathrm{Al}_{2} \mathrm{O}_{3}$ or $\mathrm{SiO}_{2} @ \mathrm{Fe}_{3} \mathrm{O}_{4}$ nanoparticles or coordinated with an axial azide ligand was also investigated. The results demonstrated that the photocatalytic activity of $\mathrm{CoPz}(\mathrm{BuS})_{8}$ loaded on $\mathrm{Al}_{2} \mathrm{O}_{3}$ was higher than that loaded on $\mathrm{SiO}_{2} @ \mathrm{Fe}_{3} \mathrm{O}_{4}$. The kinetic curves of $\mathrm{RhB}$ degradation in aqueous solutions at different $\mathrm{pH}$ indicated the pseudo first-order kinetics of the reaction. The highest degradation rate for $\mathrm{CoPz}(\mathrm{BuS})_{8}$ loaded $\mathrm{Al}_{2} \mathrm{O}_{3}$ at $\mathrm{pH}=4$ after 160 min was $84.6 \%$. However, the advantages of easier separation and recycling as well as the ability to terminate the reaction at any time for the $\mathrm{CoPz}(\mathrm{BuS})_{8}$ loaded $\mathrm{SiO}_{2} @ \mathrm{Fe}_{3} \mathrm{O}_{4}$ cannot be ignored. When electron-rich $\mathrm{NaN}_{3}$ was coordinated with $\mathrm{CoPz}(\mathrm{BuS})_{8}$ as an axial ligand and loaded on $\mathrm{Al}_{2} \mathrm{O}_{3}$, the resulting catalyst produced more active oxygen species such as $\mathrm{O}_{2}{ }^{-}$and $\mathrm{HO} \cdot$ to promote the quicker degradation of $\mathrm{RhB}$ than that by the other catalysts. For the $\mathrm{N}_{3}$-coordinated $\mathrm{CoPz}(\mathrm{BuS})_{8}$ loaded on $\mathrm{Al}_{2} \mathrm{O}_{3}$, the reactions at $\mathrm{pH}=4$ and 7 distinctly deviated from first-order kinetics, and the degradation rate reached $77.6 \%$ after $80 \mathrm{~min}$ at $\mathrm{pH}=4$.
\end{abstract}

(C) 2016, Dalian Institute of Chemical Physics, Chinese Academy of Sciences. Published by Elsevier B.V. All rights reserved.

\section{Introduction}

Porphyrazines (Pzs) and porphyrins (Prs) have similar structures to phthalocyanines (Pcs) but tend to have better solubility, especially those bearing long-chain substituents. In recent years, porphyrazinoids bearing heteroatomic substituents, especially alkylthio groups at peripheral positions, have gained increasing attention [1-6]. Although alkylthioporphyrazine complexes share the structural, redox, and magnetic properties of unsubstituted metalloporphyrazines, they show unique electronic spectra and chemical reactivity [1]. Alkylthi- oporphyrazines have been used for chemical sensing, nonlinear optics, medical applications, and cancer photodynamic therapy [2-6]. Unlike Prs, Pzs bearing a variety of substituents can be easily accessed, making them easier for electronic property adjustment and further application [7,8]. These advantages make Pzs promising alternatives to Pcs in a wide range of roles [9].

Low-pollution water is generally purified by advanced oxidation processes (AOPs), and treatment of industrial waste water is also often combined with AOPs. AOPs can degrade and even mineralize the toxic pollutants in waste water using reac-

\footnotetext{
* Corresponding author. Tel: +86-27-67843930; Fax: +86-27-67842752; E-mail: zehuizh@mail.ustc.edu.cn

\# Corresponding author. E-mail: dengkj@scuec.edu.cn

This work was supported by National Natural Science Foundation of China (20977115, 21272281), Natural Science Foundation of Hubei Province (2014CFB919), and the Science and Technology Plan Innovation Team of Wuhan City (2015070504020220).

DOI: 10.1016/S1872-2067(16)62580-9 | http://www.sciencedirect.com/science/journal/18722067 | Chin. J. Catal., Vol. 38, No. 2, February 2017
} 
tive oxygen species (ROS) like hydroxyl radicals (HO•). Such process is increasingly seen under the viewpoint of environmentally friendly or "green" chemistry, taking into account three points of unlimited natural resource: (a) oxygen (from air) as an oxidant, (b) often water as the solvent, and (c) visible light (solar radiation) for photooxidation [10]. Photochemical homogeneous and heterogeneous catalytic oxidation processes with metalloporphyrins (MPrs) and metallophthalocyanines (MPcs) have been carried out in oxygen-saturated aqueous solutions of thiols, sulfides, and phenols [10]. After MPrs or MPcs are excited, their metal center binds to an oxygen, which after a subsequent binding/interaction with a substrate, leads to the oxidized substrate in one of two ways. Singlet oxygen $\left({ }^{1} \mathrm{O}_{2}\right)$ may be formed by type-II energy transfer reactions, or a superoxide anion radical $\left(\mathrm{O}_{2}^{-}\right)$may be produced by type-I electron transfer reactions $[10,11]$. Compared with Pc, Pr is a better electron donor, thus tending to generate type-I reactions. In turn, Pc is a better light harvester than Pr, tending to generate type-II reactions. Thioporphyrazine is both a better electron donor and better light harvester than Pc and Pr, tending to generate both type-I and type-II reactions during photocatalytic degradation of pollutants $[12,13]$.

Apart from Pz, the axial ligand is also an important factor influencing the catalytic properties of metallothioporphyrazines. For example, in the early 1990s, Sorokin et al. [14] used a sulfonated iron Pc as a biomimetic catalyst to successfully degrade 2,4,6-trichlorophenol from the pulp/paper industry when acetonitrile was added to the reaction system. Acetonitrile behaved as an axial ligand to promote the catalysis. Liu et al. [15] found that low-activity $\mu$-oxodiironporphyrin converted to an active monomer with an axial chloride ligand in chlorinated solvent.

In this paper, cobalt octakis(butylthio)porphyrazine $\left(\mathrm{CoPz}(\mathrm{BuS})_{8}\right)$ was used as a biomimetic catalyst in photodegradation of rhodamine $\mathrm{B}(\mathrm{RhB})$ in water under an air atmosphere. The effects of an electron-rich cocatalyst and different inorganic carriers on the performance of the catalyst are also explored.

\section{Experimental}

\subsection{Materials and instruments}

All of the reagents used for catalyst synthesis and characterization were purchased from Aladdin Industrial Corporation. All water not specially mentioned was distilled twice before use.

Fourier transform infrared (FT-IR) spectra were recorded on a NEXUS-6700 FT-IR spectrometer (Nicolet). The Xe lamp was purchased from Applied Photophysics Limited. Analysis of the degradation products of RhB was done on a VARIAN ProS$\operatorname{tar} 210$ HPLC system. The samples were separated using a reversed-phase C18 column (200 $\mathrm{mm} \times 4.6 \mathrm{~mm})$. The X-ray diffraction (XRD) patterns were obtained on a D8-advance X-ray diffractometer (German Bruker) using $\mathrm{Cu} K_{\alpha}$ radiation. The morphologies of magnetic nanoparticles were observed on transmission electron microscopy (TEM, Tecnai G20, USA).

\subsection{Synthesis of cobaltoctakis(butylthio)porphyrazine}

Firstly, magnesium chips ( $0.056 \mathrm{~g})$ and iodine crystals as an initiator were added into $n$-butanol $(100 \mathrm{~mL})$. The mixture was stirred under reflux for $24 \mathrm{~h}$ until the magnesium chips disappeared, indicating that magnesium butoxide had successfully formed. Then, 2,3-bis(butylthio)maleonitrile [13] (2 g, 0.0078 mol) was added to the mixture, which was heated under reflux for $24 \mathrm{~h}$. The mixture was cooled to room temperature and then dried by rotary evaporation. The residue was purified by column chromatography on silica gel (ethyl acetate/petroleum ether $1 / 5$ ) to give $\mathrm{MgPz}(\mathrm{BuS})_{8}$ (1.49 g, 73.5\%).

$\mathrm{MgPz}(\mathrm{BuS})_{8}(1.041 \mathrm{~g})$ was added to $\mathrm{CF}_{3} \mathrm{COOH}(3 \mathrm{~mL})$ in the dark and stirred for $5 \mathrm{~h}$. The resulting purple solution was added to ice-water to promote precipitation. The precipitate was filtered, washed with water until the filtrate was colorless, and dried under vacuum. The residue was purified by column chromatography on silica gel (1,2-dichloroethane/petroleum ether $1: 1)$ to give $\mathrm{H}_{2} \mathrm{Pz}(\mathrm{BuS})_{8}(0.666 \mathrm{~g}, 65.4 \%)$.

$\mathrm{CoPz}(\mathrm{BuS})_{8}$ was synthesized by the reacting $\mathrm{Co}(\mathrm{OAc})_{2} \cdot 4 \mathrm{H}_{2} \mathrm{O}$ with a quantitative amount of $\mathrm{H}_{2} \mathrm{Pz}(\mathrm{BuS})_{8}$ in $\mathrm{DMF}(40 \mathrm{~mL})$ for $12 \mathrm{~h}$ at $70{ }^{\circ} \mathrm{C}$ under nitrogen atmosphere. After reaction, the mixture was added to ice-water $(200 \mathrm{~mL})$ and stirred until precipitation was complete. After cooling to room temperature, the precipitate consisting of the crude product and excess metal salts was filtered and then washed with water until the filtrate was colorless. The residue was dried under vacuum and then purified by column chromatography on silica gel $\left(\mathrm{CH}_{2} \mathrm{Cl}_{2} / \mathrm{CH}_{3} \mathrm{OH} 10 / 1\right)$ to give the final product with a yield of $73.5 \%$. For the characterization of $\mathrm{H}_{2} \mathrm{Pz}(\mathrm{BuS})_{8}$ and $\mathrm{CoPz}(\mathrm{BuS})_{8}$, see Ref. [13].

\subsection{Preparation of catalysts}

$\mathrm{CoPz}(\mathrm{BuS})_{8}$ ( $4.0 \mathrm{mg}$ ) was dissolved in $\mathrm{CH}_{2} \mathrm{Cl}_{2}(50 \mathrm{~mL})$ under ultrasonic action. The solution was added dropwise into a suspension of activated $\mathrm{Al}_{2} \mathrm{O}_{3}(1.0 \mathrm{~g})$ in $\mathrm{CH}_{2} \mathrm{Cl}_{2}(50 \mathrm{~mL})$ under stirring. The stirring was continued for $24 \mathrm{~h}$ to reach adsorption equilibrium, providing $\mathrm{Al}_{2} \mathrm{O}_{3}$-loaded $\mathrm{CoPz}(\mathrm{BuS})_{8}$. After removing the solvent by reduced pressure distillation, $\mathrm{Al}_{2} \mathrm{O}_{3}$-loaded $\mathrm{CoPz}(\mathrm{BuS})_{8}\left(\mathrm{CoPz}(\mathrm{BuS})_{8} / \mathrm{Al}_{2} \mathrm{O}_{3}\right)$ was obtained. The content of $\mathrm{CoPz}(\mathrm{BuS})_{8}$ was $4.0 \%$.

$\mathrm{SiO}_{2} @ \mathrm{Fe}_{3} \mathrm{O}_{4}$ was prepared as described in our previous work [16]. $\mathrm{CoPz}(\mathrm{BuS})_{8}$-loaded $\mathrm{SiO}_{2} @ \mathrm{Fe}_{3} \mathrm{O}_{4} \quad\left(\mathrm{CoPz}(\mathrm{BuS})_{8} /\right.$ $\mathrm{SiO}_{2} @ \mathrm{Fe}_{3} \mathrm{O}_{4}$ ) was synthesized using a similar process to that described above, and the content of $\mathrm{CoPz}(\mathrm{BuS})_{8}$ was $4.0 \%$.

\subsection{Photocatalytic degradation of RhB catalyzed by biomimetic catalysts}

$\mathrm{CoPz}(\mathrm{BuS})_{8} / \mathrm{Al}_{2} \mathrm{O}_{3}, \mathrm{CoPz}(\mathrm{BuS})_{8} / \mathrm{SiO}_{2} @ \mathrm{Fe}_{3} \mathrm{O}_{4}$, or $\mathrm{CoPz}(\mathrm{BuS})_{8} \cdot \mathrm{N}_{3} /$ $\mathrm{Al}_{2} \mathrm{O}_{3}(20 \mathrm{mg})$ was added as a catalyst to $\mathrm{RhB}$ solution $(1.0 \times$ $10^{-5} \mathrm{~mol} / \mathrm{L}, 50 \mathrm{~mL}$ ) at different $\mathrm{pH}$. The suspension was stirred for $12 \mathrm{~h}$ in the dark to establish an adsorption equilibrium before light irradiation. In a typical photocatalytic reaction, the suspension containing the catalyst and $\mathrm{RhB}$ was irradiated by a Xe lamp (light intensity $7.0 \times 10^{4}$ Lumina) in an aerated sus- 
pension for $12 \mathrm{~h}$. Aliquots of the suspension were withdrawn by a syringe after given intervals of irradiation and separated from the catalyst particles by filtration. The concentration of $\mathrm{RhB}$ in each aliquot was then analyzed by a Shimadzu UV 2600 ultraviolet-visible (UV-Vis) spectrophotometer.

\section{Results and discussion}

\section{1. $\mathrm{CoPz}(\mathrm{BuS})_{8} / \mathrm{Al}_{2} \mathrm{O}_{3}$-photocatalyzed degradation of $\mathrm{RhB}$}

The precursor 2,3-bis(butylthio)maleonitrile was tetramerized in magnesium butoxide/butanol by a template method to produce the blue-green magnesium octakis(butylthio)porphyrazine $\left(\mathrm{MgPz}(\mathrm{BuS})_{8}\right)$ with a yield of $73.5 \%$. After removing magnesium with TFA, the resulting $\mathrm{H}_{2} \mathrm{Pz}(\mathrm{BuS}) 8$ reacted with $\mathrm{Co}(\mathrm{AcO})_{2}$ to produce $\mathrm{CoPz}(\mathrm{BuS})_{8}$. The crystal structure and characterization of $\mathrm{CoPz}(\mathrm{BuS})_{8}$ were reported recently $[13,17]$. $\mathrm{CoPz}(\mathrm{BuS})_{8}$ loaded on neutral $\mathrm{Al}_{2} \mathrm{O}_{3}$ was suspended in $\mathrm{RhB}$ aqueous solution to degrade $\mathrm{RhB}$ under irradiation by a Xe lamp with aeration so as to assess the activity of biomimetic catalyst $\mathrm{CoPz}(\mathrm{BuS})_{8}$.

As shown in Fig. 1, $\mathrm{CoPz}(\mathrm{BuS})_{8} / \mathrm{Al}_{2} \mathrm{O}_{3}$ photocatalyzed degradation of $\mathrm{RhB}$ in aqueous solutions at different $\mathrm{pH}$. It indicates the first-order kinetic curves of $\mathrm{RhB}$ degradation at $\mathrm{pH}=$ 7,4 , and 9, respectively. The degradation rate at $\mathrm{pH}=4$ after $160 \mathrm{~min}$ was $84.6 \%$, while those at $\mathrm{pH}=7$ and 9 reached $65.1 \%$ and $49.2 \%$, respectively, after $12 \mathrm{~h}$ under simulated sunlight and aerated conditions. Fig. 1(D), (E), and (F) are the kinetic curves of RhB degradation in nitrogen atmosphere, without light, and without catalyst, respectively. The results demonstrate that the catalyst $\mathrm{CoPz}(\mathrm{BuS})_{8} / \mathrm{Al}_{2} \mathrm{O}_{3}$, oxygen in air, and light are necessary for effective degradation of $\mathrm{RhB}$, and acid medium also promotes the reaction.

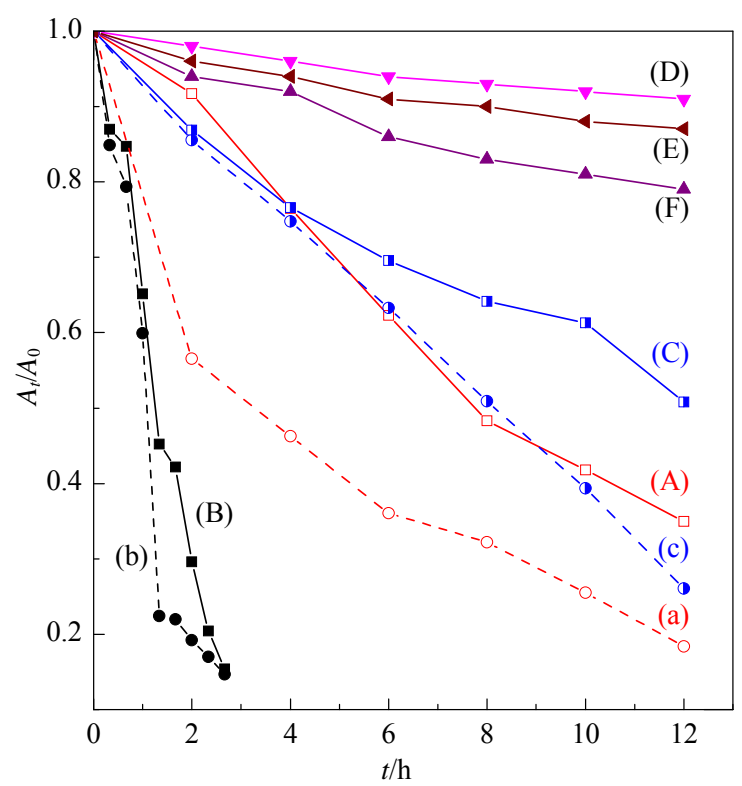

Fig. 1. $\mathrm{CoPz}(\mathrm{BuS})_{8} / \mathrm{Al}_{2} \mathrm{O}_{3}(\mathrm{~A}, \mathrm{~B}, \mathrm{C})$ and $\mathrm{CoPz}(\mathrm{BuS})_{8} \cdot \mathrm{N}_{3} / \mathrm{Al}_{2} \mathrm{O}_{3}(\mathrm{a}, \mathrm{b}, \mathrm{c})$ photocatalyzed degradation of $\mathrm{RhB}$ at different $\mathrm{pH}$ values. (A) or (a) $\mathrm{pH}$ = 7; (B) or (b) $\mathrm{pH}=4$; (C) or (c) $\mathrm{pH}=9$; (D) $\mathrm{CoPz}(\mathrm{BuS})_{8} @ \mathrm{Al}_{2} \mathrm{O}_{3} / \mathrm{N}_{2}$; (E) $\mathrm{CoPz}(\mathrm{BuS})_{8} @ \mathrm{Al}_{2} \mathrm{O}_{3} /$ dark; (F) No catalyst/air/light at $\mathrm{pH}=7$.

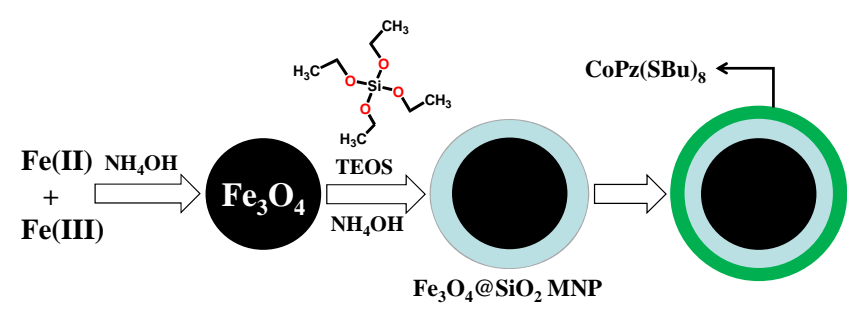

Fig. 2. The synthetic route to $\mathrm{CoPz}(\mathrm{BuS})_{8} / \mathrm{SiO}_{2} @ \mathrm{Fe}_{3} \mathrm{O}_{4}$.

\section{2. $\mathrm{CoPz}(\mathrm{BuS})_{8} / \mathrm{SiO}_{2} @ \mathrm{Fe}_{3} \mathrm{O}_{4}$-photocatalyzed degradation of $R h B$}

When the biomimetic catalyst was combined with $\mathrm{SiO}_{2} @ \mathrm{Fe}_{3} \mathrm{O}_{4}$ magnetic nanoparticles (MNPs), the separation and recycling of the catalyst were facilitated, and operating cost and properties can be optimized. Because $\mathrm{Fe}_{3} \mathrm{O}_{4} \mathrm{MNPs}$ have issues with surface acid etching and self-aggregation, the outside of the MNPs was coated with $\mathrm{SiO}_{2}$. At the same time, the $\mathrm{SiO}_{2}$ coating was able to stabilize the $\mathrm{Pz}$, thus MNPs with a $\mathrm{SiO}_{2}$ shell were chosen as a carrier for the as-synthesized $\mathrm{CoPz}(\mathrm{BuS})_{8}$. $\quad \mathrm{CoPz}(\mathrm{BuS})_{8} / \mathrm{SiO}_{2} @ \mathrm{Fe}_{3} \mathrm{O}_{4}$ was synthesized as shown in Fig. 2. Excess TEOS was used with respect to $\mathrm{Fe}_{3} \mathrm{O}_{4}$ to fully coat the $\mathrm{Fe}_{3} \mathrm{O}_{4}$ nanoparticles. The $\mathrm{SiO}_{2} @ \mathrm{Fe}_{3} \mathrm{O}_{4}$ nanoparticles were separated from the washing liquid using an external magnet after washing many times with solvent or water, while the $\mathrm{SiO}_{2}$ nanoparticles remained in the washing liquid and were removed.

$\mathrm{SiO}_{2} @ \mathrm{Fe}_{3} \mathrm{O}_{4}$ was prepared and characterized as described in our previous work [16]. FTIR results revealed that $\mathrm{CoPz}(\mathrm{BuS})_{8} / \mathrm{SiO}_{2} @ \mathrm{Fe}_{3} \mathrm{O}_{4}$ exhibited a characteristic peak from $\mathrm{CoPz}(\mathrm{BuS})_{8}$ at $2910 \mathrm{~cm}^{-1}$ (figure not shown). This indicated that the preparation of $\mathrm{CoPz}(\mathrm{BuS})_{8} / \mathrm{SiO}_{2} @ \mathrm{Fe}_{3} \mathrm{O}_{4}$ was successful.

The photocatalytic degradation of $\mathrm{RhB}$ by $\mathrm{CoPz}(\mathrm{BuS})_{8} /$ $\mathrm{SiO}_{2} @ \mathrm{Fe}_{3} \mathrm{O}_{4}$ in aqueous solutions at different pH values is presented in Fig. 3. The three solid curves indicate the pseudo-first-order kinetics of $\mathrm{RhB}$ degradation at $\mathrm{pH}=7,4$, and 9,

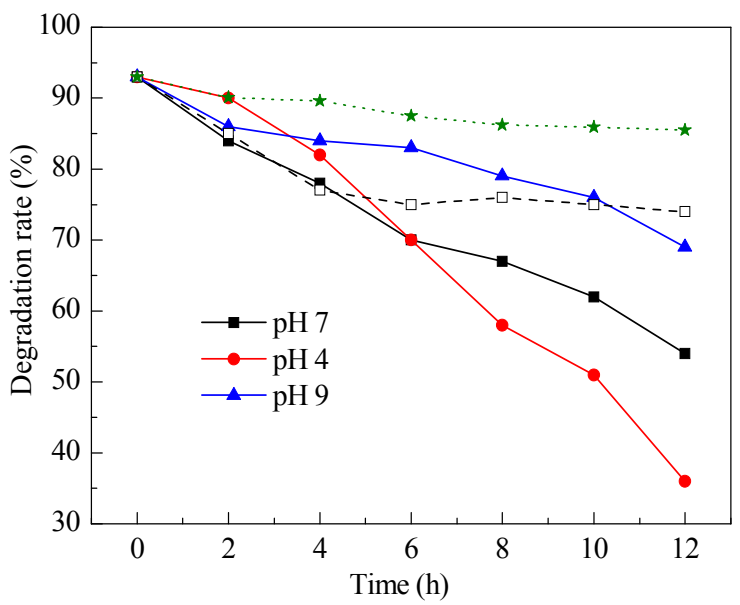

Fig. 3. Kinetic curves for the degradation of $\mathrm{RhB}$ catalyzed by $\mathrm{CoPz}(\mathrm{BuS})_{8} / \mathrm{Fe}_{3} \mathrm{O}_{4} @ \mathrm{SiO}_{2}$ at different pH. The dashed line is the results for the reaction terminated midway and the dotted line is in the presence of $\mathrm{SiO}_{2} / \mathrm{Fe}_{3} \mathrm{O}_{4}$ in neutral water. 
respectively. The degradation rate at $\mathrm{pH}=4$ after $12 \mathrm{~h}$ was $66.3 \%$, while those at $\mathrm{pH}=7$ and 9 reached $41.9 \%$ and $29.6 \%$, respectively, after $12 \mathrm{~h}$ under simulated sunlight and aerated conditions. In view of the semiconducting property of $\mathrm{Fe}_{3} \mathrm{O}_{4}$, it had some positive influence on the photocatalytic activity of $\mathrm{CoPz}(\mathrm{BuS})_{8}$ because of possible defects in the compact $\mathrm{SiO}_{2}$ coating. The degradation of $\mathrm{RhB}$ in the presence of $\mathrm{SiO}_{2} / \mathrm{Fe}_{3} \mathrm{O}_{4}$ is also shown in Fig. 3 (dotted line). RhB degradation was conducted for $4 \mathrm{~h}$ in neutral solution in the presence of catalyst, then the catalyst was removed from the system using an external magnet (Fig. 4), and the light illumination and aeration were continued. The dashed line in Fig. 3 clearly indicates that the reaction followed the degradation curve of that at $\mathrm{pH}=7$ for the first $4 \mathrm{~h}$, and then the reaction stopped because RhB concentration no longer changed. This suggests that different pollutants can be degraded using different catalyst/MNP combinations, and then the catalyst can be removed efficiently.

The repeatability and stability of $\mathrm{CoPz}(\mathrm{BuS})_{8} / \mathrm{SiO}_{2} @ \mathrm{Fe}_{3} \mathrm{O}_{4}$ in photocatalysis were also investigated. Reuse of $\mathrm{CoPz}(\mathrm{BuS})_{8}$ for seven catalytic cycles indicated that it was stable and provided repeatable results, although catalytic activity did decrease slightly because of the limit of physical absorption between $\mathrm{CoPz}(\mathrm{BuS})_{8}$ and MNPs.

The catalytic efficiency of $\mathrm{CoPz}(\mathrm{BuS})_{8} / \mathrm{Al}_{2} \mathrm{O}_{3}$ was obviously higher than that of $\mathrm{CoPz}(\mathrm{BuS})_{8} / \mathrm{SiO}_{2} @ \mathrm{Fe}_{3} \mathrm{O}_{4}$ under the same catalyst loading. Besides possessing high surface absorption ability and good chemical inertness, $\mathrm{Al}_{2} \mathrm{O}_{3}$ also has some surface oxygen vacancies that are able to promote the mobility of active oxygen in oxidation reactions [18], benefiting photocatalytic reactions. In contrast, the $\mathrm{SiO}_{2}$ coating hindered the transfer of electrons or active oxygen from $\mathrm{Fe}_{3} \mathrm{O}_{4}$ to $\mathrm{CoPz}(\mathrm{BuS})_{8}$ on the $\mathrm{SiO}_{2} / \mathrm{Fe}_{3} \mathrm{O}_{4}$ carrier [19], suppressing the photocatalytic reaction.

\section{3. $\mathrm{CoPz}(\mathrm{BuS})_{8} \cdot \mathrm{N}_{3} / \mathrm{Al}_{2} \mathrm{O}_{3}$-photocatalyzed degradation of $\mathrm{RhB}$}

Lyons et al. $[20,21]$ reported that the addition of sodium azide to oxidations catalyzed by some transition metal complexes with electron-deficient macrocycles markedly enhanced rates of low-temperature catalytic oxidation reactions in the liquid phase. When $\mathrm{NaN}_{3}$ was added to a $\mathrm{CH}_{2} \mathrm{Cl}_{2}$ solution of $\mathrm{CoPz}(\mathrm{BuS})_{8}$ (1:5) and aged for several days, $\mathrm{CoPz}(\mathrm{BuS})_{8}$ with an

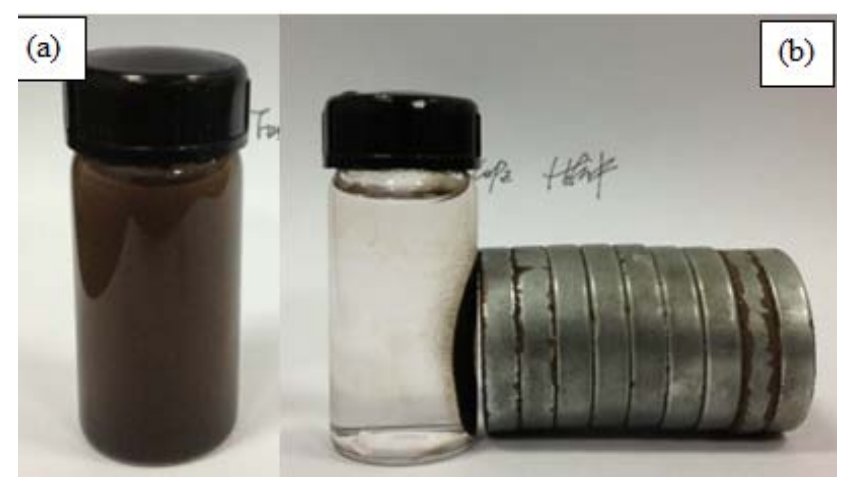

Fig. 4. Photographs of $\mathrm{CoPz}(\mathrm{BuS})_{8} / \mathrm{Fe}_{3} \mathrm{O}_{4} @ \mathrm{SiO}_{2}$ before (a) and after (b) separation from the reaction system using an external magnet.

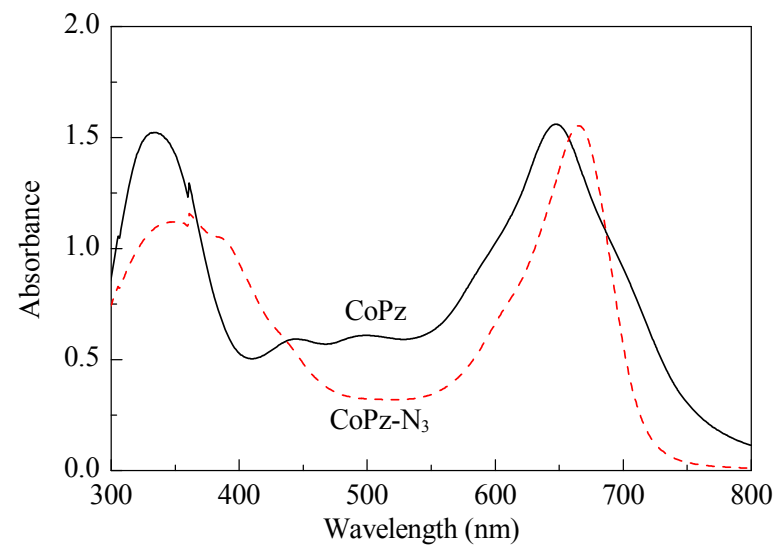

Fig. 5. UV-Vis spectra of $\mathrm{CoPz}(\mathrm{BuS})_{8}$ and $\mathrm{CoPz}(\mathrm{BuS})_{8} \cdot \mathrm{N}_{3}$.

axial $\mathrm{N}_{3}$ - ligand $\left(\mathrm{CoPz}(\mathrm{BuS})_{8} \cdot \mathrm{N}_{3}\right)$ was obtained. We were unable to obtain its crystal structure, but characterization of $\mathrm{CoPz}(\mathrm{BuS})_{8} \cdot \mathrm{N}_{3}$ by other techniques confirmed its existence. Fig. 5 shows the UV-vis spectra of $\mathrm{CoPz}(\mathrm{BuS})_{8} \cdot \mathrm{N}_{3}$ and $\mathrm{CoPz}(\mathrm{BuS})_{8}$. The B-band red-shifted by $28 \mathrm{~nm}$, and the Q-band red-shifted by $19 \mathrm{~nm}$ following axial coordination of $\mathrm{N}_{3}{ }^{-}$. The FT-IR spectrum of $\mathrm{CoPz}(\mathrm{BuS})_{8} \cdot \mathrm{N}_{3}$ displayed a characteristic peak of the $-\mathrm{N}=\mathrm{N}^{+}=\mathrm{N}^{-}$group at $2122 \mathrm{~cm}^{-1}$. In addition, the ${ }^{1} \mathrm{H}$ NMR peak at $\delta=3.17$ ppm originating from $-\mathrm{CH}_{2}-$ adjacent to a $\mathrm{S}$ atom in the BuS group shifted to lower field $(\delta=4.17 \mathrm{ppm})$ following $\mathrm{N}_{3}{ }^{-}$ axial coordination to the Co core.

When loaded on $\mathrm{Al}_{2} \mathrm{O}_{3}$, the photocatalytic efficiency of $\mathrm{CoPz}(\mathrm{BuS})_{8} \mathrm{~N}_{3}$ compared with that of $\mathrm{CoPz}(\mathrm{BuS})_{8}$ was obviously improved. Fig. 1 shows three dashed lines that are the kinetic curves for $\mathrm{RhB}$ degradation by $\mathrm{CoPz}(\mathrm{BuS})_{8} \cdot \mathrm{N}_{3} / \mathrm{Al}_{2} \mathrm{O}_{3}$, labeled (a), (b) and (c), under the same reaction conditions as used previously. Curves (a) and (b) distinctly deviated from first-order kinetics. In particular, curve (b) $(\mathrm{pH}=4$ solution) showed that the degradation rate of $\mathrm{RhB}$ reached $77.6 \%$ after $80 \mathrm{~min}$, then slowed down when the concentration of RhB was low, as illustrated in Fig. 6. HPLC was then used to further study the photooxidation degradation products, as shown in Fig. 7. The HPLC trace of the degradation products from RhB was similar to the results we previously reported [12,13]. Four

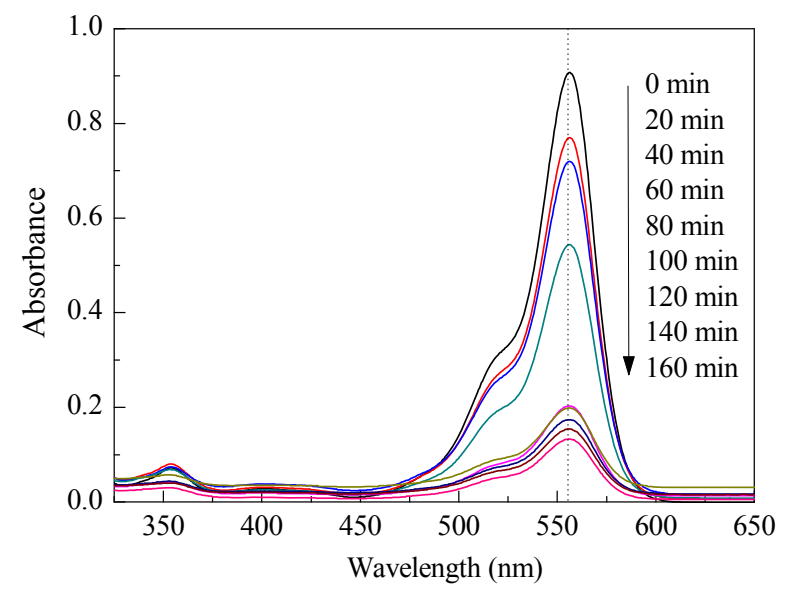

Fig. 6. UV-Vis spectral changes of $\mathrm{RhB}$ degradation catalyzed by $\mathrm{CoPz}(\mathrm{BuS})_{8} \cdot \mathrm{N}_{3}$. 


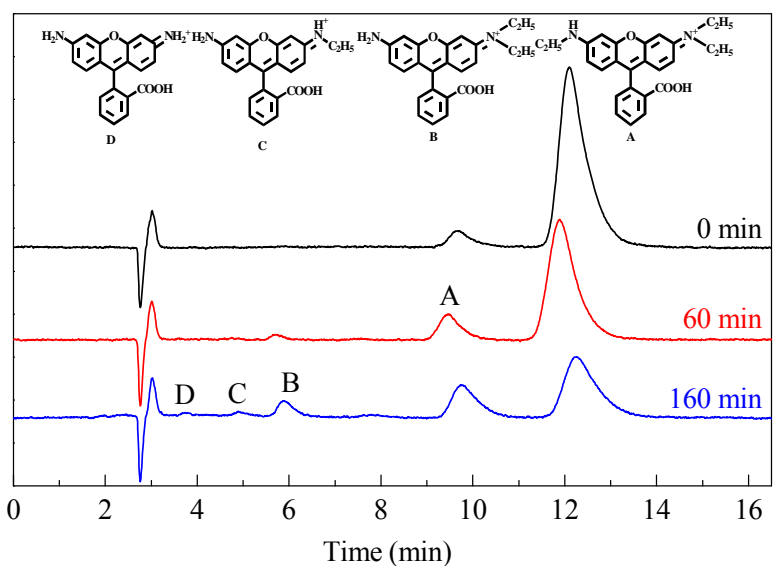

Fig. 7. Typical HPLC traces of the products obtained from photodegradation catalyzed by $\mathrm{CoPz}(\mathrm{BuS})_{8} \cdot \mathrm{N}_{3} / \mathrm{Al}_{2} \mathrm{O}_{3}$ in aqueous solution at $\mathrm{pH}=4$.

main components, $N, N$-diethyl- $N$-ethyl-rhodamine (product A, retention time $9.8 \mathrm{~min}$ ), $\mathrm{N}, \mathrm{N}$-diethyl-rhodamine (product $\mathrm{B}$, retention time $5.9 \mathrm{~min}$ ), $\mathrm{N}$-ethyl-rhodamine (product $\mathrm{C}$, retention time $4.9 \mathrm{~min}$ ), and rhodamine (product $\mathrm{D}$, retention time $3.7 \mathrm{~min}$ ), were detected by HPLC using a reversed-phase C18 column at $\lambda=500 \mathrm{~nm}$. The amount of product $A$ increased from 0 to $60 \mathrm{~min}$, and then did not change much. In contrast, the amounts of the other degradation products B, C, and D formed through the further deethylation of product A remained small during the degradation process. These results indicate that product $A$ was the main intermediate during the degradation of RhB. Hypsochromic shifts of the maximum absorption of RhB were not clearly observed in Fig. 6. Thus, the most probable mechanism of $\mathrm{RhB}$ degradation in this study was that $N, N$-diethyl- $N$-ethyl-rhodamine was the main intermediate, which was then cleaved to small molecules by ROS such as HO

The electron-rich $\mathrm{N}_{3}{ }^{-}$group of $\mathrm{CoPz}(\mathrm{BuS})_{8} \cdot \mathrm{N}_{3}$ enhanced its electron-donating ability to dioxygen to activate dioxygen to produce more ROS when axially coordinated. This was proved by catching ROS, such as $\mathrm{O}_{2}^{-}$- in Fig. 8 and HO• in Fig. 9 as well as ${ }^{1} \mathrm{O}_{2}$ using electron spin resonance (ESR) technology. The

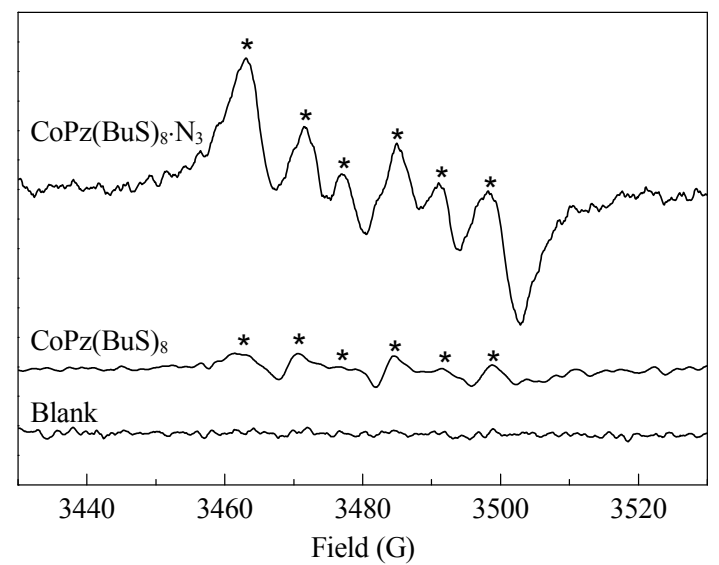

Fig. 8. Comparison of the ESR signals of the DMPO-OOH $/ \mathrm{O}_{2} \cdot \cdot$ adduct in methanol in the presence of $\mathrm{CoPz}(\mathrm{BuS})_{8}$ or $\mathrm{CoPz}(\mathrm{BuS})_{8} \cdot \mathrm{N}_{3}$ under Xe-lamp irradiation as well as without catalyst (blank).

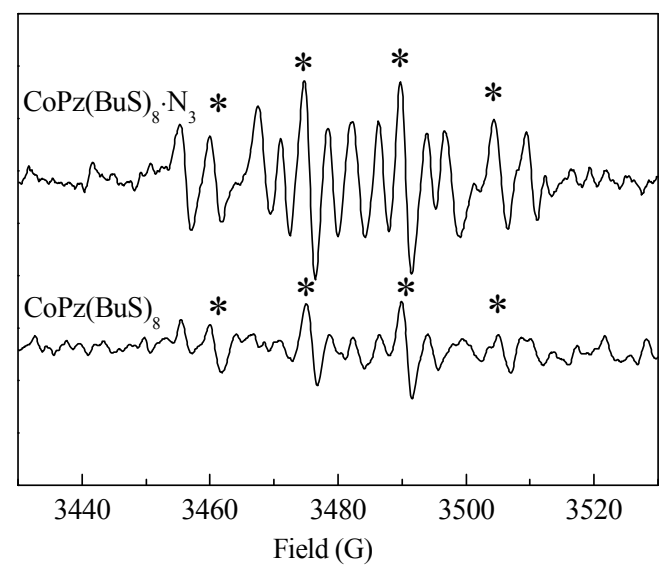

Fig. 9. Comparison of the ESR signals of the DMPO-HO• adduct in water in the presence of $\mathrm{CoPz}(\mathrm{BuS})_{8}$ or $\mathrm{CoPz}(\mathrm{BuS})_{8} \cdot \mathrm{N}_{3}$ under Xe-lamp irradiation.

axially coordinated $\mathrm{N}_{3}^{-}$group was also affected by the core Co ion to release $\mathrm{N}_{3} \cdot$ radicals, which could promote hydrogen abstraction from substrates and subsequent oxidation [21].

Comparing the performance of the three above-mentioned composite catalysts in media of different $\mathrm{pH}$, the acid medium was beneficial for the photocatalytic reaction. Our previous work [12] demonstrated that the supported metal thioporphyrazine catalyst produced not only more ${ }^{1} \mathrm{O}_{2}$ but also more $\mathrm{HO} \cdot$ in an acid medium than in neutral and basic ones, and the radical content increased with extending reaction time [12]. In contrast, in neutral and alkaline media the ROS produced did not change much over time.

\section{Conclusions}

The photocatalytic activity of $\mathrm{CoPz}(\mathrm{BuS})_{8}$ was assessed through degradation of RhB in water under Xe-lamp irradiation in air. Different carriers such as alumina and MNPs coated with $\mathrm{SiO}_{2}$, as well azide as an axial ligand were investigated. Experiments demonstrated that the photocatalytic efficiency of $\mathrm{CoPz}(\mathrm{BuS})_{8}$ loaded on $\mathrm{Al}_{2} \mathrm{O}_{3}$ was higher than that loaded on $\mathrm{SiO}_{2} @ \mathrm{Fe}_{3} \mathrm{O}_{4}$. RhB degradation in aqueous solutions of different $\mathrm{pH}$ followed pseudo-first-order kinetics. The highest degradation rate was achieved for the $\mathrm{CoPz}(\mathrm{BuS})_{8} / \mathrm{Al}_{2} \mathrm{O}_{3}$ catalyst at $\mathrm{pH}$ $=4$, reaching up to $84.6 \%$ after $160 \mathrm{~min}$. However, $\mathrm{CoPz}(\mathrm{BuS})_{8} / \mathrm{SiO}_{2} @ \mathrm{Fe}_{3} \mathrm{O}_{4}$ possessed the advantages of easier separation and recycling as well as the ability to terminate the reaction at any time. When electron-rich $\mathrm{NaN}_{3}$ was axially coordinated with $\mathrm{CoPz}(\mathrm{BuS})_{8}$ and loaded on $\mathrm{Al}_{2} \mathrm{O}_{3}$, the resulting catalyst $\mathrm{CoPz}(\mathrm{BuS})_{8} \cdot \mathrm{N}_{3} / \mathrm{Al}_{2} \mathrm{O}_{3}$ could produce active oxygen species such as $\mathrm{O}_{2}^{-\bullet}$ and $\mathrm{HO} \cdot$ to promote the rapid degradation of $\mathrm{RhB}$. Using $\mathrm{CoPz}(\mathrm{BuS})_{8} \cdot \mathrm{N}_{3} / \mathrm{Al}_{2} \mathrm{O}_{3}$, the reactions conducted at $\mathrm{pH}$ $=4$ and 7 distinctly deviated from first-order kinetics. The degradation rate reached $77.6 \%$ after $80 \mathrm{~min}$ at $\mathrm{pH}=4$, and then slowed quickly at low RhB concentration. This research may act as a reference for the design and application of biomimetic catalyst metalthioporphyrazines. Some results need to be improved further. 


\title{
Graphical Abstract
}

Chin. J. Catal., 2017, 38: 330-336 doi: 10.1016/S1872-2067(16)62580-9

\section{Effect of carrier and axial ligand on the photocatalytic activity of cobalt thioporphyrazine}

Yi Liu, Xuanmu Zhou, Zhehui Zhang*, Bingguang Zhang, Kejian Deng* South-Central Universities for Nationalities

The effects of $\mathrm{Al}_{2} \mathrm{O}_{3}$ and $\mathrm{SiO}_{2} @ \mathrm{Fe}_{3} \mathrm{O}_{4}$ carriers and axial ligand $\mathrm{NaN}_{3}$ on the photocatalytic activity of cobalt octakis(butylthio)thioporphyrazine were examined.

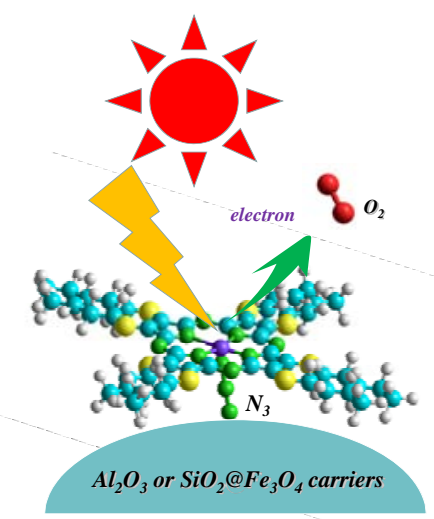

\section{References}

[1] G. Ricciardi, A. Rosa, I. Ciofini, A. Bencini, Inorg. Chem., 1999, 38, $1422-1431$.

[2] O. Worsfold, C. M. Dooling, T. H. Richardson, M. O. Vysotsky, R. Tregonning, C. A. Hunter, C. Malins, J. Mater. Chem., 2001, 11, 399-403.

[3] R. M. Christie, B. G. Freer, Dyes Pigm., 1997, 33, 107-118.

[4] B. J. Vesper, S. Lee, N. D. Hammer, K. M. Elseth, A. G. M. Barrett, B. M. Hoffman, J. A. Radosevich, J. Photochem. Photobiol. B, 2006, 82, 180-186.

[5] J. Piskorz, P. Skupin, S. Lijewski, M. Korpusinski, M. Sciepura, K. Konopka, S. Sobiak, T. Goslinski, J. Mielcarek, J. Fluorine Chem., 2012, 135, 265-271.

[6] S. Tuncer, A. Koca, A. Gül, U. Avciata, Dyes Pigm., 2012, 92, 610-618.

[7] S. Rayati, S. Zakavi, E. Bohloulbandi, M. Jafarian, M. R. avei, Polyhedron, 2012, 34, 102-107.

[8] D. Carralho da Silva, G. De Freitas-Silva, E. do Nascimento, J. S. Reboucas, P. J. S. Barbeira, M. E. M. Daide Carvalho, Y. M. Idemori, J. Inorg. Biochem., 2008, 102, 1932-41.

[9] N. Y. Oh, Y. Suh, M. J. Park, M. S. Seo, J. Kim, W. Nam, Angew. Chem.
Int. Ed., 2005, 44, 4253-4239.

[10] D. Wohrle, O. Suvorova, R. Gerdes, O. Bartels, L. Lapok, N. Baziakina, S. Makarov, A. Slodek, J. Porphyr. Phthalocyanines, 2004, 8, 1020-1041.

[11] V. Iliev, A. Mihaylova, L. Bilyarska, J. Mol. Catal. A, 2002, 184, 121-130.

[12] Z. H. Zhang, M. J. Zhang, K. J. Deng, B. G. Zhang, K. L. Lv, J. Sun, L. Q. Chen, Appl. Catal. B, 2013, 132-133, 90-97.

[13] Q. Zhou, S. Xu, C. J. Yang, B. G. Zhang, Z. Li, K. J. Deng, Appl. Catal. B, 2016, 192, 108-115.

[14] A. Sorokin, J. L. Seris, B. Meunier, Science, 1995, 268, 1163-1166.

[15] Q. Liu, C. C. Guo, Sci. Sin. Chim., 2012, 42, 1399-1416.

[16] S. G. Wang, Z. H. Zhang, B. Liu, J. L. Li, Catal. Sci. Technol., 2013, 3, 2104-2112.

[17] P. Zhou, X. Ren, Y. Liu, Y. Liu, X. Zhou, B. Zhang, C. Yang, K. Deng, Chem. Select, to be published.

[18] Y. Zhou, C. J. Xu, Y. Q. Sheng, Q. L. Zhu, Y. F. Chen, H. F. Lu, RSC Adv., 2015, 5, 91734-91741.

[19] D. Beydoun, R. Amal, G. Low, S. McEvoy, J. Mol. Catal. A, 2002, 180, 193-200.

[20] J. E. Lyons, P. E. Ellis Jr, Appl. Catal. A, 1992, 84, L1-L6.

[21] J. E. Lyons, P. E. Ellis Jr, S. N. Shaikh, Inorg. Chim. Acta, 1998, 270, $162-168$.

\section{载体和轴向配体对八正丁硫基含硫四氮杂钴卟啉光催化活性的影响}

\author{
刘义，周泫沐，张泽会", 张丙广，邓克俭 ${ }^{*}$ \\ 中南民族大学化学与材料科学学院, 催化材料科学国家民委-教育部重点实验室, 湖北武汉 430074
}

摘要: 将八正丁硫基四氮杂钴卟啉 $\left(\mathrm{CoPz}(\mathrm{BuS})_{8}\right)$ 分别负载到载体 $\mathrm{Al}_{2} \mathrm{O}_{3}$ 和 $\mathrm{SiO}_{2} @ \mathrm{Fe}_{3} \mathrm{O}_{4}$ 以及与配体叠氮轴向配位, 并在模拟 太阳光的氙灯照射下通入空气, 通过降解水中染料罗丹明 $\mathrm{B}(\mathrm{RhB})$ 来评估其光催化活性. 载体 $\mathrm{Al}_{2} \mathrm{O}_{3}$ 有高的比表面积和好的 化学惰性, 其表面还存在一些氧空位以促进氧化反应中活性氧的流动; 虽然磁性纳米颗粒( $\mathrm{MNP}$ ) $\mathrm{Fe}_{3} \mathrm{O}_{4}$ 表面存在酸腐蚀和 自聚集问题, 但在MNP外面包覆一层具有较好吸附和稳定性能的 $\mathrm{SiO}_{2}$ 膜, 因而也是较好的催化剂载体. 富电子的 $\mathrm{NaN}_{3}$ 可增 强某些缺电子的过渡金属大环络合物催化氧化反应, 是较好的轴向配体.

在不同 $\mathrm{pH}$ 水溶液中降解RhB的动力学曲线表明, 反应为准一级. 复合催化剂 $\mathrm{CoPz}(\mathrm{BuS})_{8} / \mathrm{Al}_{2} \mathrm{O}_{3}$ 上 $\mathrm{RhB}$ 降解率在 $\mathrm{pH}=4$ 时 经 $160 \mathrm{~min}$ 达到 $84.6 \%$, 在 $\mathrm{pH}=7$ 和 $\mathrm{pH}=9$ 时经 $12 \mathrm{~h}$ 分别达到 $65.1 \%$ 和 $49.2 \%$. 复合催化剂 $\mathrm{CoPz}(\mathrm{BuS})_{8} / \mathrm{SiO}_{2} @ \mathrm{Fe}_{3} \mathrm{O}_{4}$ 的透射电镜 (TEM)和红外光谱(FTIR)表征表明, $\mathrm{SiO}_{2}$ 包覆完整, 复合粒子在 $1083 \mathrm{~cm}^{-1}$ 有 $\mathrm{SiO}_{2}$ 的吸收峰, 在 $2910 \mathrm{~cm}^{-1}$ 有 $\mathrm{CoPz}(\mathrm{BuS})_{8}$ 的烷基 
吸收峰, 说明 $\mathrm{NMP}$ 上存在 $\mathrm{SiO}_{2}$ 和 $\mathrm{CoPz}(\mathrm{BuS})_{8}$, 表明复合粒子制备成功; 其光催化反应的降解率在 $\mathrm{pH}=4,7$ 和 9 时经 $12 \mathrm{~h}$ 分别 达到 $66.3 \%, 41.9 \%$ 和 $29.6 \%$. 尽管 $\mathrm{CoPz}(\mathrm{BuS})_{8}$ 负载到 $\mathrm{Al}_{2} \mathrm{O}_{3}$ 上比负载到 $\mathrm{SiO}_{2} @ \mathrm{Fe}_{3} \mathrm{O}_{4}$ 上活性高, 但后者分离容易, 可重复使用, 尤其是可随时终止反应. 这意味着不同的污染物可用性能不同的催化剂/MNP系统去除, 而催化剂可高效回收.

当富电子的 $\mathrm{NaN}_{3}$ 与 $\mathrm{CoPz}(\mathrm{BuS})_{8}$ 在轴向配位并负载到 $\mathrm{Al}_{2} \mathrm{O}_{3}$ 上时, $\mathrm{CoPz}(\mathrm{BuS})_{8}$ 的紫外-可见光谱 $\mathrm{B}$ 带红移 $28 \mathrm{~nm}, \mathrm{Q}$ 带红移 $19 \mathrm{~nm}, \mathrm{FTIR}$ 在 $2122 \mathrm{~cm}^{-1}$ 出现一个 $-\mathrm{N}=\mathrm{N}^{+}=\mathrm{N}^{-}$特征吸收峰, 临近 $\mathrm{S}$ 原子的烷基链 $-\mathrm{CH}_{2}-$ 的核磁峰从 $3.17 \mathrm{ppm}$ 移向低场 4.17 $\mathrm{ppm}$, 表明 $\mathrm{N}_{3}{ }^{-}$配位成功. 利用 $\mathrm{ESR}$ 自由基捕获技术发现, 该复合催化剂能活化分子氧, 产生比复合催化剂 $\mathrm{CoPz}\left(\mathrm{BuS}_{8} / \mathrm{Al}_{2} \mathrm{O}_{3}\right.$ 更多的 $\mathrm{O}_{2}{ }^{-}$和 $\mathrm{HO}^{\circ}$ 等活性物种. 在 $\mathrm{pH}=4$ 和 $\mathrm{pH}=7$ 水溶液中的反应明显偏离了一级反应动力学, 促进 $\mathrm{RhB}$ 的快速降解, 在 $\mathrm{pH}$ $=4$ 时 $80 \mathrm{~min}$ 内降解率达到 $77.6 \%$, 之后因 RhB浓度迅速降低而慢下来. 同时, 在 $\mathrm{pH}=7$ 和 $\mathrm{pH}=9$ 时经 $12 \mathrm{~h}$ 降解率也分别达到 $81.7 \%$ 和 $74.3 \%$. RhB降解产物主要有 $N, N$-二乙基- $N$-乙基罗丹明、 $N, N$-二乙基罗丹明、 $N$-乙基罗丹明和罗丹明. 其中第一个 产物是主要中间体, 随后被活性氧物种分裂成小分子和矿化.

比较了不同 $\mathrm{pH}$ 媒介中三个复合催化剂的活性, 发现酸性条件有利于光催化反应. 这是因为在酸性溶液中产生的活性 物种比在中性和碱性溶液中多, 且随着反应时间增加而增加所致. 而在中性和碱性条件下, 活性物种改变很少. 稳定性实 验表明, 复合催化剂是稳定的, 可以重复使用, 复合催化剂 $\mathrm{CoPz}(\mathrm{BuS})_{8} / \mathrm{SiO}_{2} @ \mathrm{Fe}_{3} \mathrm{O}_{4}$ 重复使用7次后活性基本保持不变.

关键词: 含硫四氮杂钴卟啉; 光催化活性; 氧化铝; $\mathrm{SiO}_{2} @ \mathrm{Fe}_{3} \mathrm{O}_{4}$; 轴向配体; 叠氮化钠

收稿日期: 2016-08-30. 接受日期: 2016-10-15. 出版日期: 2017-02-05.

*通讯联系人. 电话: (027)67843930; 传真: (027)67842752; 电子信箱: zehuizh@mail.ustc.edu.cn

通讯联系人. 电子信箱: dengkj@scuec.edu.cn

基金来源: 国家自然科学基金 (20977115, 21272281); 湖北省自然科学基金 (2014CFB919); 武汉市科技创新计划 (2015070504020220).

本文的英文电子版由Elsevier出版社在ScienceDirect上出版(http://www.sciencedirect.com/science/journal/18722067). 